\title{
ZOOLOGY
}

DOI https://doi.org/10.30525/978-9934-26-006-3-7

\section{АНАЛІЗ СТІЙКОСТІ ГІБРИДІВ КУКУРУДЗИ ДО ПОШКОДЖЕНЬ ЗАХІДНИМ КУКУРУДЗЯНИМ ЖУКОМ (DIABROTICA VIRGIFERA VIRGIFERA LE CONTE) НА ТЕРИТОРІЇ ЧЕРКАСЬКОЇ ОБЛАСТІ}

\author{
Зубенко О. Г. \\ кандидат біологічних наук, \\ старший виклад кафедри біології, екології та агротехнологій \\ Черкаський національний університет імені Богдана Хмельницького \\ Білясва К. О. \\ студентка четвертого курсу \\ Навчально-науковий інститут природничих наук \\ Черкаського національного університету імені Богдана Хмельнищького \\ м. Черкаси, Україна \\ Експансія західного кукурудзяного жука (Diabrotica virgifera \\ virgifera Le Conte), на теренах України, що спостерігається в останні \\ роки ускладнює карантинну ситуацію. Зважаючи на те, що шкідник не \\ так давно з'явився на території України, його шляхи розповсюдження, \\ особливості розвитку та методи, якими найефективніше можна його \\ виявити, не досить розроблені, тому їх дослідження є актуальними і \\ вкрай необхідними [5, с. 24]. \\ Інтенсивність інвазій залежить від ступеня міжнародної інтеграції в \\ усіх iï проявах: торгівельних, туристичних та інших міждержавних \\ зв'язків. Щорічне розширення міждержавних торгово-економічних \\ відносин значно сприяє збільшенню обсягів імпорту та експорту \\ рослинної продукції і створює додаткові умови для проникнення в \\ Україну нових адвентивних видів. Їх карантинний статус та економічне \\ значення для України не завжди відомі і прогнозовані, як і не вивчені їх \\ біологічні особливості, екологічна пластичність та заходи боротьби 3 \\ ними [3, с. 48]. \\ Скоротити потік інвазій у країну інколи не вдається через певні \\ обставини, оскільки інвазійні потоки мають різну направленість \\ [1, c. 168].
}


Головною передумовою будь-якої системи захисту рослин $\epsilon$ сучасний фітосанітарний моніторинг і прогноз поширення шкідливих організмів, який повинен представляти собою систему збору, накопичення, аналізу i використання фітосанітарної, зокрема, карантинної інформації з метою цілеспрямованого і оптимального проведення відповідних заходів [2, с. 24].

У 1992 році вперше в Свропі на кукурудзяних полях в околицях Белграда неподалік від міжнародного аеропорту Сурчин був виявлений північноамериканський шкідник кукурудзи - західний кукурудзяний жук D. v. virgifera Le Conte [4, c. 30].

На території України вперше виявлено у 2001 році в Закарпатській області. Щороку ареал його невпинно збільшується й наразі D. v. virgifera виявляють на посівах кукурудзи в Закарпатській, Львівській, ІваноФранківській, Тернопільській, Чернівецькій, Вінницькій, Житомирський, Хмельницькій, Волинській областях [5, с. 24]. В Черкаській області вперше виявлено у 2017 році в Уманському, Звенигородському, КорсуньШевченківському і Маньківському районах.

Процес поширення $D$. v. virgifera $€$ результатом дії комплексу різних факторів, як природного, так і антропічного характеру. Природній шлях поширення - це активні перельоти імаго в пошуках кормових рослин, що $є$ етіологічною особливістю шкідника. Одним із головних чинників, що сприяє інвазії $D$. v. virgifera та його подальшому розповсюдженню, $\epsilon$ наявність придатної для його розвитку рослини-господаря кукурудзи. Вирощування кукурудзи в умовах монокультури забезпечить жука постійною кормовою базою та призведе до значного його розповсюдження і шкідливості в Україні [5, с.25].

Аналіз площ зараження D. v. virgifera районів Черкаської області у 2020 році свідчить, що найбільшими вони були у КорсуньШевченківському (92,7 га), Звенигородському (89,5 га), Тальнівському районах (76,8 га). Дещо менші території заражені карантинним шкідником у Городищенському (40,6 га), Шполянському (25,8 га), Уманському (15,3 га), Христинівському та Монастирищенському районах (11,5 і 10,3 га відповідно). В цілому за три роки моніторингу $D$. v. virgifera у Черкаській області встановлено, що 3 кожним роком чисельність фітофага стрімко зростає.

За трьохрічний період наших спостережень фітофаг заселив поля прилеглі до заплав річок та низовинні місця. У 2018 році майже не відмічалася інвазія в межах районів, але спостерігали різке збільшення чисельності на охопленій території. У Шполянському та Уманському районах відмічали поширення $D$. v. virgifera вздовж транспортних магістралей. Були виявлені одиничні екземпляри, що свідчить про безперешкодний спосіб розселення фітофага. 
Дослідження показали, що початок льоту жуків відбувається за суми ефективних температур $\left(\sum \mathrm{t}_{\text {еф. }}\right)$ вище $15^{\circ} \mathrm{C}$ в межах $750-850^{\circ} \mathrm{C}$. Імаго фітофага заселяло посіви із першої декади липня до третьої декади жовтня. На початок льоту ми відмічали 6 екземплярів на рослину. Пік чисельності зафіксовано у третій декаді липня, коли $\sum \mathrm{t}_{\mathrm{e \phi}}$ становила близько $880-960^{\circ} \mathrm{C}$. В цей час відмічали 25 екз./рослину. Після максимального льоту імаго шкідника спостерігали поступове спадання чисельності. У першій декаді серпня інтенсивність льоту зменшується до 20,5\%, а починаючи 3 першої декади вересня літ фітофага знижується до $10 \%$.

Приблизно через два тижні від початку льоту відмічали відкладання яєць самками. У першій декаді серпня самка відкладає близько 15 \% яєць. У третій декаді серпня самки відкладають лише близько $25 \%$. До закінчення льоту імаго, яке відбувається в останніх числах жовтня, самки можуть реалізувати свій репродуктивний потенціал лише на $50 \%$.

Аналізуючи стійкість сортів та гібридів кукурудзи встановлено, що найбільш стійкими до пошкоджень жуками є ранньостиглі гібриди кукурудзи (ФАО 100-199) - Дельфін, ДКС 3476, ДКС 3871. Так, частка недостатньостійких і нестійких гібридів кукурудзи группах ФАО 400499 та ФАО 500-600 сягала близько 80\%. Із збільшенням тривалості вегетації рослин прослідковується тенденція до збільшення пошкодженості кукурудзи фітофагом. Найбільша частка нестійких гібридів - 50\% належить до групи пізніх гібридів (ФАО 500-600) - ДМ Нейтив, Харківський 43 М (Донор М), Харківський 45 М (Індустрія М), Любава МВ, Штандарт. Таким чином, на пошкодженість кукурудзи фітофагом впливає не тільки рівень стійкості рослин, але й тривалість їх вегетаційного періоду.

3 врахуванням ступеня стійкості, а також урожайності за групами стиглості з усього масиву досліджуваних гібридів кукурудзи, доцільно вирощувати в зоні підвищеної шкодочинності D. v. virgifera: ранньостиглі - Дельфін, ЕС Пароллі, ДКС 3476, ДКС 3871; середньоранні - ЕС Лаймс, НК Джитаго, НК Делітоп, ДКС 3472; середньостиглі - ДКС 4590. Ці гібриди мають достатній рівень стійкості до пошкоджень D. v. virgifera, високу урожайність, або навіть за більш значного пошкодження характеризуються високим рівнем витривалості у порівнянні з середнім у групі.

Додатково проведені в 2020 році дослідження попередньо відібраних гібридів різної стійкості до D. v. virgifera при штучному лабораторному заселенні шкідником дозволили більш точно встановити, стійкість гібридів, що підтверджується постійними високими показниками чисельності та шкодочинності фітофага. Так, 
всі відібрані гібриди кукурудзи виявили однакову стійкість, як за природного, так і за штучного лабораторного заселення D. v. virgifera.

Аналізуючи результати досліджень встановили, що в середньому урожайність непошкоджених рослин високостійких та стійких гібридів була на 0,34-0,72 т/га більшою ніж пошкоджених, середньостійких - 0,260,37 т/га. Вирощування стійких гібридів в 2019 році в умовах підвищеної чисельності $D$. v. virgifera забезпечило збереження 9-11\% врожаю.

Таким чином, стійкі гібриди та сорти в агроценозі кукурудзи відіграють суттєву модифікуючу роль стосовно $D$. v. virgifera.

Окрім стійкості гібридів кукурудзи до пошкоджень $D$. v. virgifera впливають строки сівби. Строк сівби певною мірою також впливає на густоту і висоту стеблостою, які визначають мікроклімат в посівах, а тим самим фізіологічний стан рослин і популяцію D. v. virgifera.

У фази проростання насіння та росту рослин кукурудзи личинки ЗКЖ найбільш $є$ шкодочинними. У пізніші строки сівби посіви знищуються до $22,8 \%$. Нестійкими є гібриди пізньої групи.

Найнижча пошкодженість сходів рослин D. v. virgifera була при ранніх строках сівби кукурудзи (12.04-20.04) - 5\% у гібриду ДКС 3472. Значно більше були пошкоджені гібриди Штандарт, ДМС 4010 та ДМС 3111 - 12,3\%, 13,0\% і 13,3\% відповідно. Найбільш пошкоджені рослини були при більш пізніх строках сівби. Так, гібриди ДМС 4010 і ДМ Санрайз були пошкоджені на $22,8 \%$ i $21,7 \%$ відповідно. При відстроченні сівби на 18-19 діб пошкодженість рослин буде збільшуватися до $40 \%$.

\section{Література:}

1. Андреянова Н. I. Ризик проникнення та розповсюдження Diabrotica virgifera virgifera Le Conte у вільні від шкідника регіони України. Науковий вісник Ужгородського університету. Ужгород, 2010. № 29. С. 167-169.

2. Омелюта В. П., Філатова Н. К., Адамчук О. С., Бабідорич М. М. Західний кукурудзяний жук. Тактика запобігання поширення та шкодочинності. Карантин $і$ захист рослин. 2004. № 11. С. 23-24.

3. Огляд поширення карантинних організмів в Україні на 1 січня 2018 р. / за ред. Симонов В. С. К.: Юніверсал, 2018. 116 с.

4. Ижевский С. С. Западный кукурузный жук в Европе. Защита и карантин растений. 2003. № 5. С. 30-32.

5. Мовчан О. М. Поширення діабротики в Україні. Карантин $i$ захист рослин. 2006. № 7. С. 24-25. 